\title{
Gastroesophageal reflux and asthma: Can the paradox be explained?
}

\author{
Stephen K Field MD CM FRCPC \\ Division of Respiratory Medicine, University of Calgary Medical School, \\ Calgary, Alberta
}

SK Field. Gastroesophageal reflux and asthma: Can the paradox be explained? Can Respir J 2000;7(2):167-176.

BACKGROUND AND OBJECTIVE: The reported effects of asthma on gastroesophageal reflux (GER), effects of GER on asthma and the effects of antireflux therapy on asthma are conflicting. The purpose of this paper is to review the evidence for a relationship between the two conditions.

DESIGN: A search of the MEDLINE 1966 to 1999 database, combining the terms GER and asthma, was used to identify studies of the effects of acid perfusion of the esophagus, the physiological equivalent of GER and the effects of both medical and surgical antireflux therapy on asthma. Bibliographies of the identified papers were also reviewed.

MAIN RESULTS: The collected evidence suggests that GER causes asthma symptoms but has minimal effects on pulmonary function. Both medical and surgical antireflux therapy can improve asthma symptoms and asthma medication requirements without improving pulmonary function. The paradox of GER causing symptoms without affecting pulmonary function may be because of the retrosternal discomfort that accompanies GER increases minute ventilation and respiratory sensation.

CONCLUSIONS: Despite an extensive body of literature, many questions remain about the relationship between GER and asthma. A review of the data suggests a strong association between the two conditions, and that GER worsens asthma symptoms without affecting pulmonary function. Asymptomatic GER does not worsen asthma. Antireflux therapy may have a role in asthma patients with symptomatic GER, possibly being most beneficial for those with refluxassociated respiratory symptoms. Unfortunately, many studies contain flaws such as a lack of controls and small sample sizes. Further properly designed controlled trials, including ones that measure the effects of GER and antireflux therapy on quality of life, are needed to understand better the role of GER in asthma.

Key Words: Bronchial reactivity; Chest pain; Cough; Dyspnea; Fundoplication; Heartburn; Vagal reflexes

voir page suivante

$\mathrm{T}$ The 1892 edition of Sir William Osler's (1) textbook of medicine included the caveat that people with asthma should not eat a large evening meal to avoid wheezing at night. Bray (2) proposed in 1934 that gastric distention causes bronchospasm by a vagally mediated reflex. It was the 1960s, however, before data demonstrating an association between asthma and gastroesophageal reflux (GER) were available $(3,4)$. Several investigators reported that the people 


\section{Reflux gastroøsophagien et asthme : pouvons- nous expliquer ce paradoxe?}

HISTORIQUE ET OBJECTIF : Les effets rapportés de l'asthme sur le reflux gastroœsophagien (RGO), des effets du reflux gastroœsophagien sur l'asthme et des effets du traitement antireflux sur l'asthme sont en contradiction. Le but du présent article est de rechercher les preuves d'une relation entre les deux affections.

MODÈLE : Une recherche dans la base de données Medline de 1966 à 1999 combinant les termes «GER » et «asthma» a permis d'identifier les études portant sur les effets d'une perfusion acide dans l'œsophage, l'équivalent physiologique d'un RGO, et les effets du traitement médical et chirurgical antireflux sur l'asthme. Les bibliographies des articles identifiés ont aussi été passées en revue.

PRINCIPAUX RÉSULTATS : Les preuves recueillies laissent à penser que le RGO cause les symptômes de l'asthme mais n'a que des effets minimes sur la fonction pulmonaire. Les traitements médical et chirurgical antireflux peuvent tous deux améliorer les symptômes de l'asthme et diminuer le besoin de médication contre l'asthme sans cependant améliorer la fonction pulmonaire. Le paradoxe du RGO causant des symptômes sans détériorer la fonction pulmonaire pourrait résider dans le fait que la douleur rétrosternale qui accompagne le RGO accroît la ventilation minute et la sensibilité respiratoire.

CONCLUSIONS : Malgré un nombre imposant d'articles, de nombreuses questions demeurent au sujet d'une relation entre RGO et asthme. Une revue des données laisse à penser qu'il existe une forte association entre ces deux affections, et que le RGO aggrave les symptômes de l'asthme sans détériorer la fonction pulmonaire. Le RGO asymptomatique n'aggrave pas l'asthme. Le traitement antireflux pourrait être indiqué chez les patients asthmatiques atteints d'un RGO symptomatique, et serait le plus bénéfique pour ceux dont les symptômes respiratoires sont associés au reflux. Malheureusement, de nombreuses études contiennent des failles comme le manque de témoins et la taille insuffisante des échantillons. D'autres essais comparatifs bien conçus, y compris ceux qui mesurent les effets du RGO et du traitement antireflux sur la qualité de vie, sont nécessaires pour mieux comprendre le rôle du RGO dans l'asthme. with asthma in their large series of patients undergoing antireflux procedures experienced improvement and, in some cases, cure of their asthma after successful surgery. These observations stimulated research into the nature of the relationship between GER and asthma. Some investigators implicated GER as an important asthma trigger and reported that treating GER was important for good asthma control (5-7). Others, however, concluded that GER does not adversely affect asthma and that antireflux therapy is not beneficial for asthma control (8-10). This review presents the apparently conflicting data surrounding the relationship between the two conditions, offers an explanation for the strong association between them and suggests indications for investigating and treating GER in patients with asthma.

\section{ASSOCIATION BETWEEN GER AND ASTHMA}

Both asthma and GER are relatively common conditions in the general population. Twenty per cent of telephone survey respondents reported at least three episodes of symptomatic GER per month (11). Both the prevalence and severity of GER are greater in asthma (Figure 1). The prevalence of GER in asthma patients has ranged from 30\% to $90 \%$ depending on which subjects were studied and the methods used to determine the presence of GER (12). In a controlled, questionnaire-based survey of consecutive patients attending a university asthma clinic, $45 \%$ had pyrosis regularly compared with only $10 \%$ of the patients in two control groups (13). Irwin et al (5) reported that two-thirds of patients referred to their university-based clinic with difficult to control asthma had symptomatic GER. Sontag and colleagues $(14,15)$ evaluated outpatient asthma clinic attendees at a Veterans Administration hospital and found that more than $80 \%$ had abnormal esophageal $\mathrm{pH}$ monitoring studies, nearly $60 \%$ had a hiatus hernia and $40 \%$ had erosive esoph- agitis. Balson et al (16) reported that $75 \%$ of pediatric patients with severe asthma had abnormal $\mathrm{pH}$ monitoring studies. These reports suggest a strong association between the two conditions, but the nature of the relationship between them is controversial. The relationship may be because of asthma causing GER, bronchodilator medication causing GER or, as most investigators have assumed, GER causing asthma.

\section{DOES ASTHMA CAUSE GER?}

GER should be more prevalent in asthma because cough and the greater respiratory effort accompanying it increase the pressure gradient across the lower esophageal sphincter, which favours the retrograde movement of gastric contents (13). Singh and Jain (17) reported that treatment with ephedrine and the resulting improvement in five asthma patients reduced GER. Moote and colleagues (18) performed methacholine challenge tests in patients with mild asthma and in normal subjects while they were undergoing esophageal $\mathrm{pH}$ monitoring and found that GER was increased in people with asthma. In a similarly designed study, Ekstrom and Tibbling (19) were unable to demonstrate increased GER in asthma patients undergoing histamine challenge testing. The differences among the studies cannot be explained by the use of different bronchoconstricting agents because methacholine increases lower esophageal sphincter pressure and histamine increases gastric acid secretion.

\section{DO BRONCHODILATORS CAUSE GER?}

Both theophylline and beta agonists relax the lower esophageal sphincter, which should facilitate GER, and theophylline increases gastric acid production (20-22). Therapeutic doses of beta agonists, however, do not increase GER in asthma patients or normal subjects $(23,24)$. The findings with theophylline are not consistent. Approximately 
half of investigators have reported that theophylline increases GER, but the remainder were unable to demonstrate an effect (25-30). Two groups did not find an increased prevalence of GER in asthma patients receiving regular bronchodilator medication $(13,14)$. In another study, bronchodilator medication use was similar in asthma patients with and without GER (31). These cross-sectional studies may have been unable to identify an association between theophylline use and more severe GER because patients who develop GER are more likely to discontinue its use.

\section{GER AND RESPIRATORY SYMPTOMS}

Several authors reported that asthma patients experience respiratory symptoms during episodes of symptomatic GER. Ekstrom et al (32) found that 56\% of asthma patients with GER experienced reflux-associated respiratory symptoms (RARS), ie, cough, dyspnea or wheezing, during episodes of symptomatic GER. Field et al (13) found that $41 \%$ experienced RARS and $28 \%$ used their rescue beta agonist during episodes of symptomatic GER. Goodall et al (33) reported a correlation between the severity of GER and asthma symptoms. Harding et al (34) reported a temporal correlation between GER, documented by ambulatory $\mathrm{pH}$ monitoring, and respiratory symptoms in asthma patients. The relationship between GER and asthma symptoms led investigators to study the effects of simulated and real GER on pulmonary function.

\section{ANIMAL STUDIES}

The foregut and respiratory tract have common embryological origins and share a number of reflexes that coordinate breathing and deglutition. Diaphragmatic tone contributes to lower esophageal sphincter function $(35,36)$. In both feline and canine models, esophageal distention stimulates mechanoreceptors in the afferent limb of a vagal reflex that relaxes the crural diaphragm, facilitating the movement of the food bolus through the lower esophageal sphincter $(37,38)$. Harding and Titchen (39) reported that hydrochloric acid stimulates esophageal mechanoreceptors. Mansfield et al (40) showed that acid perfusion (AP) of the canine esophagus increased airway tone and that this response was abolished after bilateral cervical vagotomy. They postulated that the increase in airway tone during AP was because of a vagally mediated reflex. Hamamoto et al (41) reported that AP of the esophagus caused inflammatory changes in the guinea pig bronchial tree. They proposed that AP of the esophagus might trigger asthma by stimulating the production of neurogenic inflammatory mediators. A recent study of the composition of expectorated sputum found no difference in inflammatory mediators in asthma patients with and without GER (42).

Tuchman and colleagues (43) found that intratracheal instillation of $0.05 \mathrm{~mL}$ of $0.2 \mathrm{~N}$ hydrochloric acid increased airway resistance substantially more than $10 \mathrm{~mL} 0.2 \mathrm{~N}$ hydrochloric acid instilled into the feline esophagus, leading them to conclude that microaspiration could be the mechanism by which GER triggered asthma. Consistent with this

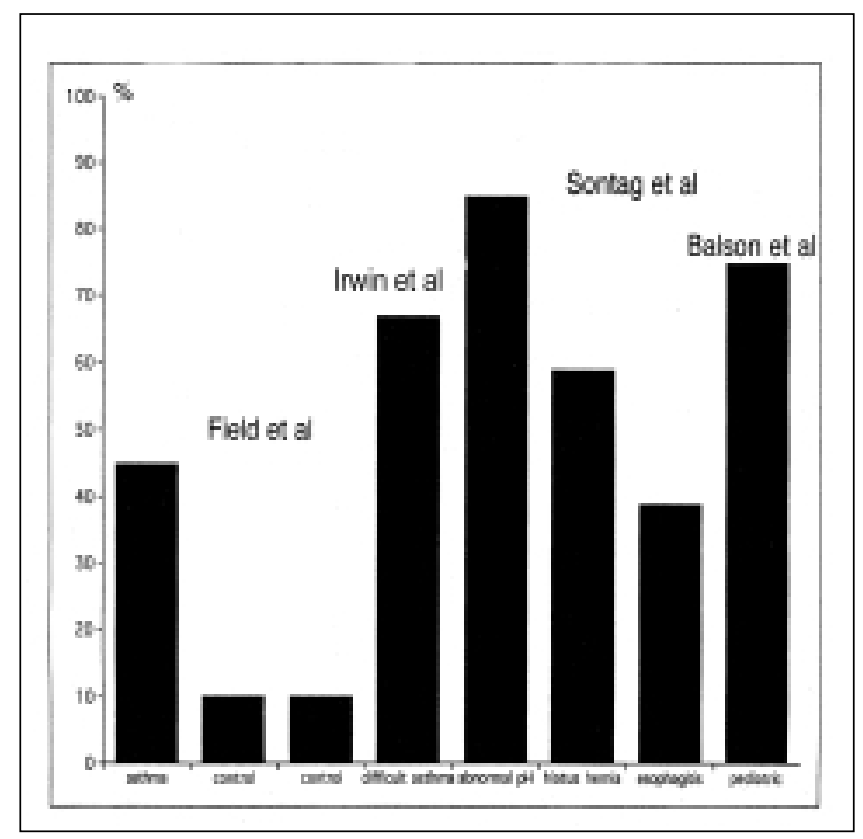

Figure 1) The prevalence of gastroesophageal reflux (GER) in different groups of asthma patients. The first three histograms on the left are the percentage of asthma patients and subjects in two separate control groups with symptomatic GER, respectively. Data adapted from reference 13. The next column, fourth from the left, is the percentage of difficult to control patients with asthma with GER. Data adapted from reference 5. The next three columns are the percentage of asthma clinic attendees with abnormal ambulatory $\mathrm{pH}$ findings, hiatus hernia and erosive esophagitis, respectively. Data adapted from references 14 and 15. The column on the right is the percentage of children with severe asthma found with abnormal ambulatory $\mathrm{pH}$ monitoring findings. Data adapted from reference 16

hypothesis, Ishikawa and co-workers (44) recently reported that AP of the esophagus did not increase airway tone but laryngeal stimulation with hydrochloric acid did.

\section{EFFECTS OF AP OF THE ESOPHAGUS ON PULMONARY FUNCTION IN HUMANS}

Vagal reflexes originating in the esophagus are present in humans. Esophageal distention inhibits diaphragm function (45). Wright et al (46) reported the effects of AP of the esophagus on heart rate, forced expiration volume in $1 \mathrm{~s}$ $\left(\mathrm{FEV}_{1}\right)$ and arterial saturation in 136 subjects. $\mathrm{FEV}_{1}$ and arterial saturation were the same during AP and saline perfusion of the esophagus, but the decline in heart rate was greater during AP of the esophagus. The reduction in heart rate suggests that AP increases vagal tone but does not cause a clinically significant decline in pulmonary function (46). Unfortunately, this study did not separate the results from the patients with asthma from those of normal subjects and patients with chronic bronchitis. Lodi et al (47) performed vagal testing in asthma patients with symptomatic GER and found that the majority displayed cardiovascular responses consistent with increased vagal activity compared with controls. Vagal activity, however, did not correlate with asthma severity. 


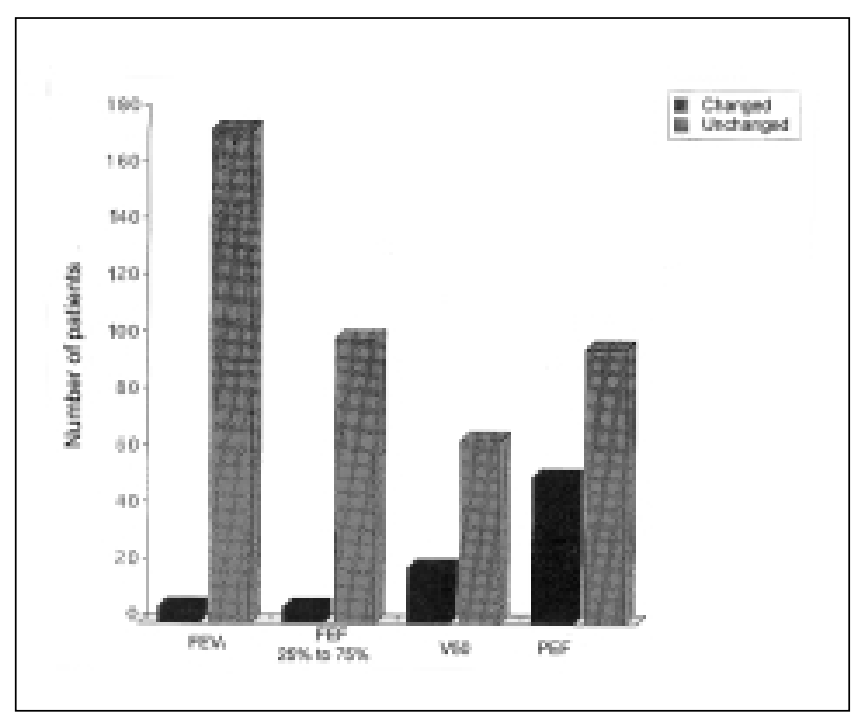

Figure 2) The effect of acid perfusion (AP) of the esophagus on pulmonary function of people with asthma. The pairs of bars show the number of patients with asthma in studies that do (black bar) and do not (gray bar) show a significant change in forced expiration volume in $1 \mathrm{~s}\left(F E V_{1}\right)$, forced midexpiratory flow $\left(F E F_{25-75 \%)}\right.$ and peak expiratory flow (PEF) during AP. V50 Flow at 50\% vital capacity. Reproduced with permission from reference 63

\section{HUMAN STUDIES OF THE EFFECTS OF GER ON PULMONARY FUNCTION}

Most investigators assumed that GER triggered asthma because of the effects of AP in animal studies, and the development of respiratory symptoms in asthma patients during symptomatic GER. A number of investigators have reported the effects of AP on pulmonary function in people with asthma $(8,9,46,48-62)$. These studies were designed to maximize the likelihood that the effects of GER on pulmonary function would be identified. Investigators measured a number of spirometric, flow-volume loop and resistance indexes during AP. Twelve of 18 papers on the effects of GER or AP of the esophagus in asthma published in the English-language literature reported that one or two pulmonary function indexes declined during AP or GER (63). In general, these studies found small but statistically significant changes in the more sensitive and less specific parameters, but statistical corrections for multiple measurements were not included in the analysis. A critical review of these studies found that, for each parameter, only a minority of patients experienced any decline (Figure 2) (63). Segregating the data by whether asthma patients had symptomatic GER did not affect the findings (63).

Aspiration of gastric contents causes inflammatory changes in the airway (64). Mendelson (65) reported that wheezing was a feature of massive aspiration. Although acid aspiration that was severe enough to decrease tracheal $\mathrm{pH}$ at a location $2 \mathrm{~cm}$ above the carina caused a significant decrease in peak expiratory flow (PEF) in their patients with asthma, Jack et al (48) were unable to show that AP of the esophagus caused a significant decline in PEF. Relatively large amounts of aspirate can cause changes in pulmonary

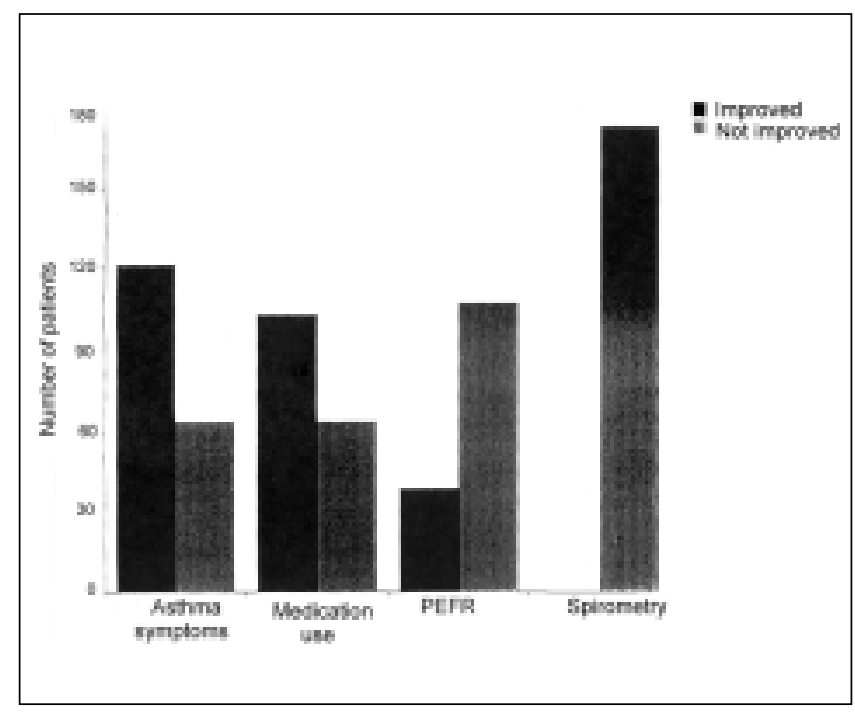

Figure 3) Summarized data on the effects of medical antireflux therapy on asthma symptoms, asthma medication use, peak expiratory flow rate (PEFR) and spirometry in eight randomized, placebo controlled trials. Each pair of columns shows the number of patients in the studies who improved (black bar) and did not (gray bar) improve. Reproduced with permission from reference 76

function; however, this is not typical in patients with GER. Several investigators reasoned that, if microaspiration, repeated aspiration of minute amounts of gastric contents, was a cause of bronchoconstriction, then GER into the proximal esophagus would be a better predictor of pulmonary function changes than GER limited to the lower esophagus (59). Proximal reflux, however, did not correlate with changes in lung function (66).

\section{EFFECTS OF MEDICAL ANTIREFLUX THERAPY IN ASTHMA}

Reports of asthma improving with successful antireflux surgery led investigators to study the effects of $\mathrm{H} 2$ receptor blockers in patients with asthma with GER $(32,33,56,67-69)$. Initially, there were concerns that these medications may cause clinical worsening of asthma because of $\mathrm{H} 2$ receptor blockade in the bronchial tree (70-72). Although some investigators reported that $\mathrm{H} 2$ receptor blockers increase bronchial reactivity, their use in asthma appears to be safe (73-75). A recent critical review identified 12 English-language studies of the effects of medical antireflux therapy in people with asthma with GER (76). In the eight controlled studies, two used cimetidine, four ranitidine and two omeprazole $(10,32,33,67-69,77,78)$. A critical review of the controlled studies indicates that medical antireflux therapy improved GER symptoms, asthma symptoms and asthma medication requirements (76). Medical antireflux therapy, however, did not improve PEF or spirometry (Figure 3). Since the publication of this report, two more controlled trials with omeprazole have been published $(79,80)$. The addition of the results from these two studies to the critical review did not affect its conclusions (76). A recent study of the effects of lansopra- 


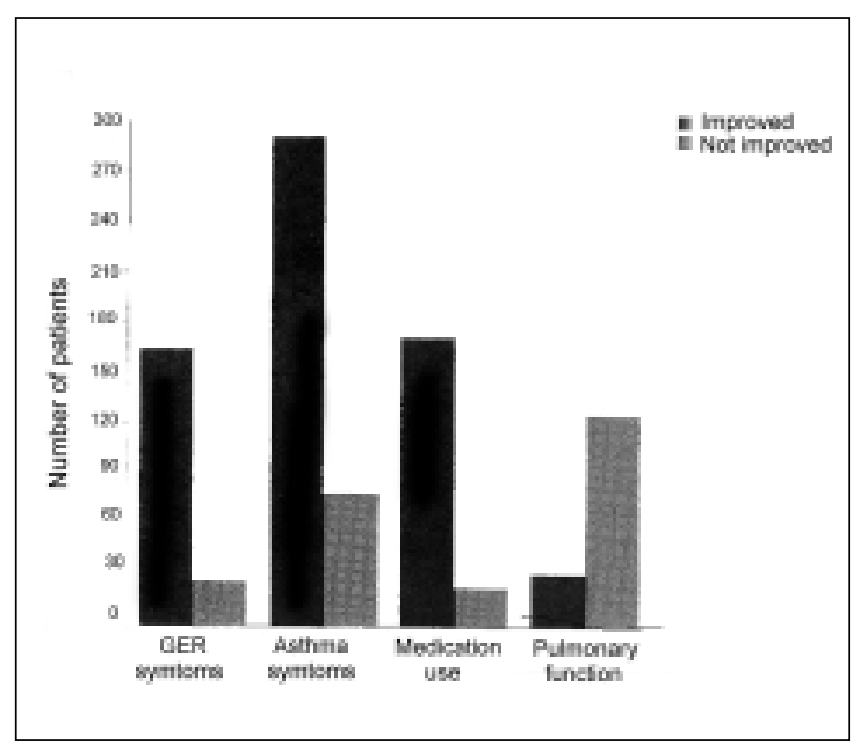

Figure 4) The effects of antireflux surgery on gastroesophageal reflux (GER) symptoms, asthma symptoms, asthma medication requirements and pulmonary function testing. The dark bars indicate the number of subjects who experienced an improvement, and the lighter bars indicate the number of patients who did not improve. Reproduced with permission from reference 82

zole found that it also improved respiratory symptoms and quality of life, but neither PEF nor spirometry improved in asthma patients with GER (81).

\section{EFFECTS OF SURGICAL ANTIREFLUX THERAPY}

Since the 1960s, antireflux surgery has been reported to be beneficial in asthma patients with GER $(3,4)$. A recent review identified 24 reports, with more than 400 patients, on the effects of antireflux surgery in asthma (82). The two controlled trials demonstrated that antireflux surgery improves asthma symptoms and asthma medication requirements but does not improve pulmonary function $(67,83)$. The addition of the results of the open reports to the controlled trials does not change the conclusions. Antireflux surgery improves GER symptoms, asthma symptoms and asthma medication requirements but does not improve pulmonary function (Figure 4) (3,4,6,84-102). Limiting the analysis to the effects of Nissen fundoplication, the current gold standard surgical procedure, did not alter the findings (Figure 5) (82).

Several other reports of the effects of antireflux surgery have been described. Hunter and colleagues (103) reported symptomatic improvement in 25 of 30 asthma patients following fundoplication. Unfortunately, neither the effects on asthma medication requirements nor pulmonary function were reported. A retrospective study of 39 people with asthma among 600 patients undergoing antireflux surgery found that asthma symptoms and medication requirements improved postoperatively. Pulmonary function was not reported (104). Ruth et al (105) found that fundoplication improved asthma symptoms but did not improve pulmonary

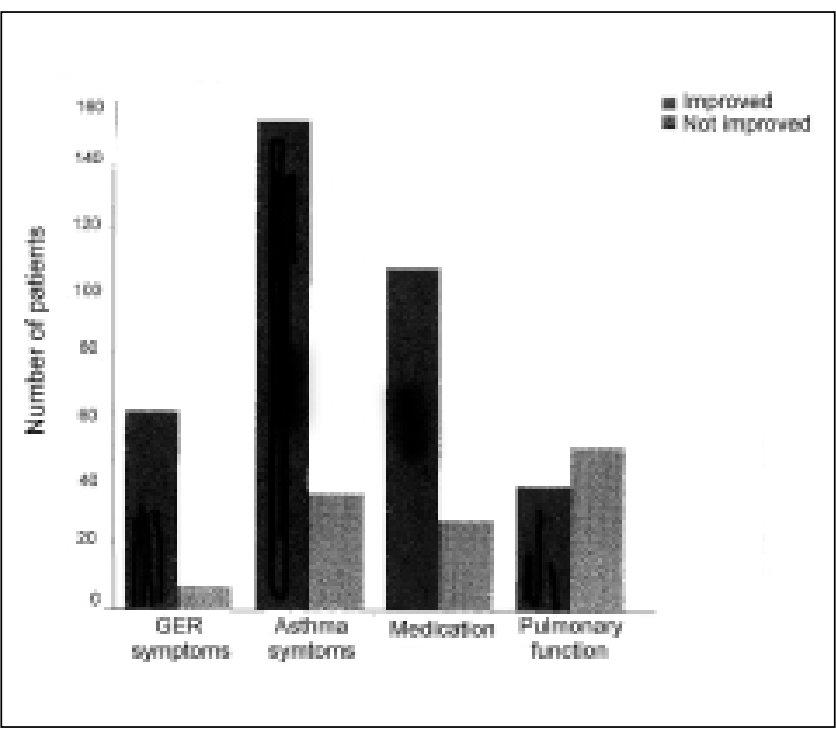

Figure 5) The effects of open and laparascopic Nissen fundoplication on gastroesophageal reflux (GER) symptoms, asthma symptoms, asthma medication requirements and pulmonary function testing. The black bars show the number of patients who improved postoperatively, and the gray bars show the number of patients who did not improve in the nine reports in which Nissen fundoplication was used. Reproduced with permission from reference 82

function or bronchial reactivity to methacholine. The additional data do not change the findings of the recent critical review on antireflux surgery (82). The effects of both surgical and medical antireflux therapy on asthma show a paradox. Antireflux therapy improves asthma symptoms and asthma medication requirements but does not improve pulmonary function (82).

\section{CAN THE PARADOX BE EXPLAINED?}

Previous investigators of the relationship between GER and asthma are divided into two opposing camps. Some believe that GER worsens asthma and treating GER improves it. Others have disagreed and interpreted the data to indicate that GER does not affect asthma. Another explanation is that GER does not affect pulmonary function but causes respiratory symptoms requiring asthma medication. An obvious question is whether this apparent paradox can be explained.

GER is a frequent cause of chronic cough that responds to antireflux therapy (106-108). Orringer (109) suggested that the chest discomfort associated with GER may produce a subjective feeling of shortness of breath in patients. There are several reports that GER can cause dyspnea in patients with normal pulmonary function and bronchial reactivity, and that treating GER relieves dyspnea $(110,111)$.

The anesthesia literature contains several reports that pain can increase minute ventilation (112). Respiratory effort is the most important determinant of respiratory sensation (113). Retrosternal discomfort because of GER can increase minute ventilation that, in turn, increases the sensation of respiratory effort that is experienced as dyspnea in some 


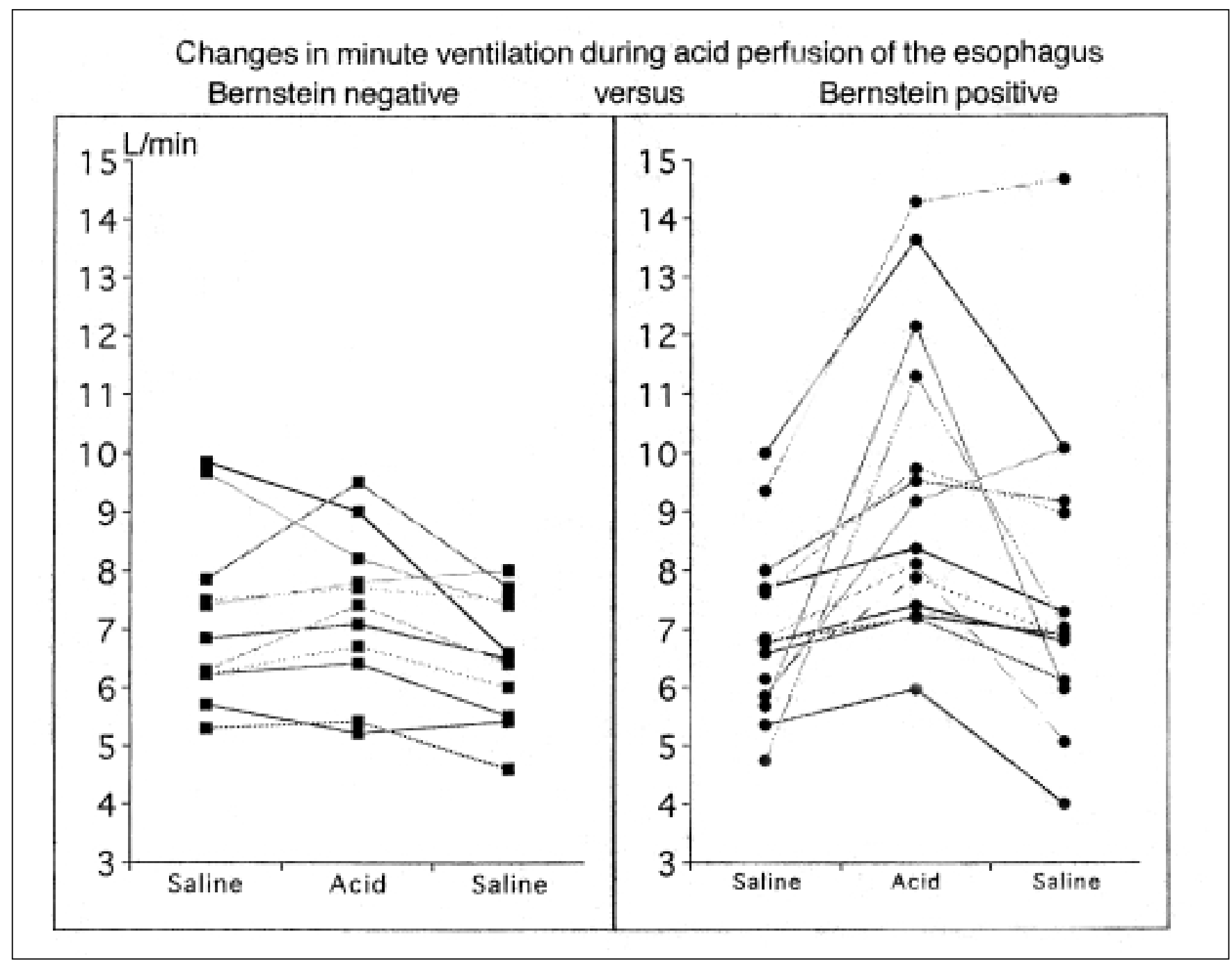

Figure 6) Minute ventilation of individual patients during saline and acid perfusion periods. Patients are grouped according to whether they had a positive or negative acid perfusion test result. The minute ventilation for the Bernstein-positive patients was 7.0 $\pm 1.6,9.4 \pm 2.6$ and $7.8 \pm 2.5 \mathrm{~L} / \mathrm{min}$ in the first saline, acid and second saline perfusion periods, respectively. The minute ventilation for the Bernstein-negative patients was 7.2 $\pm 1.5,7.4 \pm 1.5$ and $6.6 \pm 1.2 \mathrm{~L} / \mathrm{min}$ in the first saline, acid and second saline perfusion periods, respectively. Reproduced with permission from reference 114 .

patients. To test this hypothesis, nonasthmatic patients with normal pulmonary function who were undergoing motility testing as part of their investigation for esophageal disease were given an acid reflux test (114). Patients who developed pain during the acid reflux test increased their minute ventilation, whereas those with negative acid reflux tests did not (Figure 6). The increase in respiratory sensation correlated with the increase in minute ventilation (114). The majority of subjects with a positive acid reflux test described the increased respiratory sensation as an awareness of their greater respiratory effort that was not unpleasant. The two subjects with the greatest increases in minute ventilation described their respiratory sensation as air hunger that was unpleasant (114). Similar increases in minute ventilation in asthma patients with abnormal pulmonary function may cause even greater changes in respiratory sensation.

Hyperventilation and hypocarbia are recognized triggers of bronchospasm (52). The increase in minute ventilation accompanying retrosternal discomfort in asthma patients with symptomatic GER may explain the reports of wheezing associated with symptomatic GER. GER, therefore, may serve as an indirect trigger of bronchospasm in sensitive individuals.

\section{ALTERNATIVE EXPLANATIONS OF THE PARADOX}

Other explanations have been offered to explain the inability to show consistently that GER worsens pulmonary function or that antireflux therapy improves it. Asthma patients are sensitive to a variety of triggers including allergens, exercise and cigarette smoke. The response to different triggers varies among asthma patients. Similarly, not all asthma patients are sensitive to GER. Nonasthmatic patients with respiratory symptoms may be diagnosed to be asthmatic and treated for 
asthma (115). Inclusion of similar patients in studies would preclude showing an effect on pulmonary function because of GER or antireflux therapy. Pulmonary function testing was not routinely done in some of the investigations, increasing the likelihood that nonasthmatic patients were included. Moreover, asthma patients may experience reflux-like symptoms in the absence of physiological GER $(31,32)$. The absence of either asthma or GER in some members of the study cohort may explain the inability to show an effect. Moreover, continuing asthma medications during the studies may have blunted the response to GER. AP of the esophagus increases cough sensitivity to capsaicin (116). Instead of a direct effect on airway tone, GER may indirectly increase the sensitivity to other triggers.

There are additional reasons why antireflux therapy failed to improve pulmonary function. Most studies did not confirm that antireflux therapy adequately suppressed GER in the study cohort. The study by Harding et al (117) was the exception, showing that GER remained abnormal in a third of their subjects receiving the standard dose of omeprazole, $20 \mathrm{mg}$ once daily. Even if acid suppression is sufficient, inflammatory changes in the airway may take more than one year to heal (118). Most studies were relatively short, and Meier (77) reported persistent esophagitis even after six weeks of daily therapy with $40 \mathrm{mg}$ of omeprazole. Most studies of the effects of both medical and surgical antireflux therapy contained small numbers of patients, and beta error cannot be excluded as the reason that a positive effect was not demonstrated (82).

Trigger avoidance is the recommended first line approach to asthma management (119). Irwin et al (5) reported that GER was the most common trigger in patients with difficult to control asthma. Some have advocated an aggressive approach to both the investigation and treatment of GER in asthma even in the absence of GER symptoms (5-7). Others reported that GER has no adverse effect on pulmonary function and treating it does not improve asthma management $(9,10,56,58,60,68,80)$. The uncertainty surrounding the relationship between asthma and GER is reflected by the ambivalence in the recommendations for the evaluation and treatment of GER in the National Institutes of Health-sponsored asthma guidelines (120). Analysis of the available literature suggests that an approach that falls between the extremes of ignoring GER and aggressively investigating for and treating asymptomatic GER in asthma is appropriate.

Most physicians would agree that the presence of asthma should not affect the appropriate investigation and treatment of patients with symptomatic GER. The evaluation and treatment of GER should also be considered for asthma patients with less severe GER symptoms, especially if they have RARS (32). The literature available does not support the investigation for and treatment of GER in asthma patients lacking GER symptoms. A full discussion of the controversy surrounding the relative merits and cost effectiveness of medical versus surgical antireflux therapy is beyond the scope of this review. The available data, however, suggest that medical and surgical antireflux therapy have similar effects on asthma symptoms and asthma medication requirements in patients with symptomatic GER $(76,82)$. The limited amount of available controlled data does not show that either medical or surgical antireflux therapy has a clinically significant effect on pulmonary function $(76,82)$. Further properly controlled studies of the effects of antireflux therapy in asthma should be undertaken. It is mandatory that they be adequately powered with adequate numbers of subjects and measure GER and pulmonary function objectively, confirm that GER is controlled for an adequate treatment period and confirm the effects of antireflux therapy on pulmonary function. Future studies should also measure the effects of antireflux therapy with properly validated quality of life questionnaires $(79,81)$. Quality of life measures may be the best way to assess the effects of antireflux therapy because it appears to affect asthma symptoms but not pulmonary function.

\section{SUMMARY}

There is a strong association between GER and asthma but the nature of the relationship remains controversial. Although GER causes respiratory symptoms in asthma patients, it does not appear to affect pulmonary function. Moreover, both medical and surgical antireflux therapy improve asthma symptoms and medication requirements but do not improve pulmonary function. The apparent paradox of the effects of GER and antireflux therapy in asthma patients may be explained by discomfort-induced changes in minute ventilation.

\section{REFERENCES}

1. Osler WB. The principles of medicine. Philadelphia: Lea and Febiger, 1892:498.

2. Bray GW. Recent advances in the treatment of asthma and hay fever. Practitioner 1934;34:368-79.

3. Overholt RH, Voorhees RJ. Esophageal reflux as a trigger in asthma. Dis Chest 1966;49:464-6.

4. Urschel HC, Paulson DL. Gastroesophageal reflux and hiatal hernia: complications and therapy. J Thorac Cardiovasc Surg 1967;53:21-32.

5. Irwin RS, Curley FJ, French CL. Difficult-to-control asthma: contributing factors and outcome of a systemic management protocol. Chest 1993;103:1662-9.

6. Perrin-Fayolle M, Gormand F, Braillon G, et al. Long-term results of surgical treatment in asthmatic patients. Chest 1989;96:40-5.

7. Choy D, Leung R. Gastro-oesophageal reflux disease and asthma. Respirology 1997;2:163-8.

8. Ekstrom T, Tibbling L. Esophageal acid perfusion, airway function, and symptoms in asthmatic patients with marked bronchial reactivity. Chest 1989;96:995-8.

9. Wesseling G, Brummer RJ, Wouters EF, Ten Velde GP. Gastric asthma? No change in respiratory impedance during intraesophageal acidification in adult asthmatics. Chest 1993;104:1733-6.

10. Ford GA, Oliver PS, Prior JS, Butland RJA, Wilkinson SP. Omeprazole in the treatment of asthmatics with nocturnal symptoms and gastro-oesophageal reflux: a placebo-controlled cross-over study. Postgrad Med J 1994;70:350-4.

11. A Gallup Survey on Heartburn Across America. Princeton: The Gallup Organization, 1988.

12. Harding SM, Richter JE. The role of gastroesophageal reflux in chronic cough and asthma. Chest 1997;111:1389-1402.

13. Field SK, Underwood M, Brant R, Cowie RL. Prevalence of 
gastroesophageal reflux symptoms in asthma. Chest 1996;109:316-22.

14. Sontag SJ, O'Connell S, Khandelwal S, et al. Most asthmatics have reflux with or without bronchodilator therapy. Gastroenterology 1990;99:613-20.

15. Sontag SJ, Schnell TG, Miller TQ, et al. Prevalence of oesophagitis in asthmatics. Gut 1992;33:872-6.

16. Balson BM, Kravitz EKS, McGeady SJ. Diagnosis and treatment of gastroesophageal reflux in children and adolescents with severe asthma. Ann Allergy Asthma Immunol 1998;81:159-64.

17. Singh V, Jain NK. Asthma as a cause for, rather than a result of gastroesophageal reflux. J Asthma 1983;20:241-3.

18. Moote DW, Lloyd DA, McCourtie, Wells GA. Increase in gastroesophageal reflux during methacholine-induced bronchospasm. J Allergy Clin Immunol 1986;78:619-23.

19. Ekstrom TK, Tibbling LI. Can mild bronchospasm reduce gastroesophageal reflux? Am Rev Respir Dis 1989;139:52-5.

20. Foster LJ, Trudeau WL, Goldman AL. Bronchodilator effects on gastric acid secretion. JAMA 1979;241:2613-5.

21. Zfass AM, Prince R, Allen FN, Farrar JT. Inhibitory beta adrenergic receptors in the human distal esophagus. Am J Dig Dis 1970;15:303-10.

22. Goyal RK, Rattan S. Mechanism of the lower esophageal sphincter relaxation: action of prostaglandin E1 and theophylline. J Clin Invest 1973;52:337-41.

23. Michoud MC, Leduc T, Proulx F, et al. Effect of salbutamol on gastroesophageal reflux in healthy volunteers and patients with asthma. J Allergy Clin Immunol 1991;87:762-7.

24. Schindlbeck NE, Heinrich C, Huber RM, Muller-Lissner SA. Effects of albuterol (salbutamol) on esophageal motility and gastroesophageal reflux in patients with asthma. JAMA 1988;260:3156-8.

25. Berquist WE, Rachelefsky GS, Rowshan N, Siegel S, Katz R, Welch M. Quantitative gastroesophageal reflux and pulmonary function in asthmatic children and normal adults receiving placebo, theophylline, and metaproterenol sulfate therapy. J Allergy Clin Immunol 1984;73:253-8.

26. Stein MR, Towner TG, Weber RW, et al. The effect of theophylline on lower esophageal sphincter pressure. Ann Allergy 1980;45:238-41.

27. Berquist WE, Rachelefsky GS, Kadden M, et al. Effect of theophylline on gastroesophageal reflux in normal adults. J Allergy Clin Immunol 1981;67:407-11.

28. Ekstrom T, Tibbling L. Influence of theophylline on gastrooesophageal reflux and asthma. Eur J Clin Pharmacol 1988;35:353-6.

29. Hubert D, Gaudric M, Guerre J, Lockhart A, Marsac J. Effect of theophylline on gastroesophageal reflux in patients with asthma. J Allergy Clin Immunol 1988;81:1168-74.

30. Ruzkowski CJ, Sanowski RA, Austin J, R Thowedder JJ, Waring JP. The effects of inhaled albuterol and oral theophylline on gastroesophageal reflux in patients with gastroesophageal reflux disease and obstructive lung disease. Arch Intern Med 1992;152:783-5.

31. Vincent D, Cohen-Jonathan AM, Leport J, et al. Gastro-oesophageal reflux prevalence and relationship with bronchial reactivity in asthma. Eur Respir J 1997;10:2255-9.

32. Ekstrom T, Lindgren BR, Tibbling L. Effects of ranitidine treatment on patients with asthma and a history of gastro-oesophageal reflux: a double blind crossover study.Thorax 1989;44:19-23.

33. Goodall RJR, Earis JE, Cooper DN, Bernstein A, Temple JG. Relationship between asthma and gastro-oesophageal reflux. Thorax 1981;36:116-21.

34. Harding SM, Guzzo MR, Richter JE. 24-hour esophageal pH testing in asthmatics: respiratory symptom correlation with esophageal acid events. Chest 1999;115:654-9.

35. Welch RW, Gray JE. Influence of respiration on recordings of lower esophageal sphincter pressure in humans. Gastroenterology 1982;83:590-4.

36. Boyle JT, Altschuler SM, Nixon TE, Tuchman DN, Pack AI, Cohen S. Role of the diaphragm in the genesis of lower esophageal sphincter pressure in the cat. Gastroenterology 1985;88:723-30.

37. Monges H, Salducci J, Naudy B. Dissociation between the electrical activity of the diaphragmic dome and crura muscular fibres during esophageal distension, vomiting and eructation. J Physiol 1978;74:547-56.

38. Oyer LM, Knuth SL, Ward DK, Bartlett D Jr. Reflex inhibition of crural diaphragmatic activity by esophageal distention in cats. Respir Physiol 1989;77:195-202.

39. Harding R, Titchen DA. Chemosensitive vagal endings in the oesophagus of the cat. J Physiol 1975;247:52P-3P. (Abst)

40. Mansfield LE, Hameister HH, Spaulding HS, Smith NJ, Glab N The role of the vagus nerve in airway narrowing caused by intraesophageal hydrochloric acid provocation and esophageal distention. Ann Allergy 1981;47:431-4.

41. Hamamoto J, Kohrogi H, Kawano O, et al. Esophageal stimulation by hydrochloric acid causes neurogenic inflammation in the airways in guinea pigs. J Appl Physiol 1997;82:738-45.

42. Parameswaran K, Allen C, Anvari M, Kamada D, Efthimiadis A, Hargreave F. Gastroesophageal reflux (GER) and asthma. Eur Respir J 1999;14:26S. (Abst)

43. Tuchman DN, Boyle JT, Pack AI, et al. Comparisons of airway responses following tracheal or esophageal acidification in the cat. Gastroenterology 1984;87:872-81.

44. Ishikawa T, Sekizawa S-I, Sant'ambrogio FB, Sant'ambrogio G. Larynx vs esophagus as reflexogenic sites for acid-induced bronchoconstriction in dogs. J Appl Physiol 1999;86:1226-30.

45. Rimmer KP, Whitelaw WA, Graham K, Field SK. Mechanisms of hypoxemia during panendoscopy. J Clin Gastroenterol 1989;11:17-22.

46. Wright RA, Miller SA, Corsello BF. Acid-induced esophagobronchial-cardiac reflexes in humans. Gastroenterology 1990;99:71-3.

47. Lodi U, Harding SM, Coghlan HC, Guzzo MR, Walker LH Autonomic regulation in asthmatics with gastroesophageal reflux. Chest 1997; 111:65-70.

48. Jack CIA, Calverley PMA, Donnelly RJ, et al. Simultaneous tracheal and oesophageal $\mathrm{pH}$ measurements in asthmatic patients with gastrooesophageal reflux. Thorax 1995;50:201-4.

49. Harding SM, Schan CA, Guzzo MR, Alexander RW, Bradley LA, Richter JE. Gastroesophageal reflux-induced bronchoconstriction. Is microaspiration a factor? Chest 1995;108:1220-7.

50. Mansfield LE, Stein MR. Gastroesophageal reflux and asthma: a possible reflex mechanism. Ann Allergy 1978;41:224-6.

51. Kjellen G, Tibbling L, Wranne B. Bronchial obstruction after oesophageal acid perfusion in asthmatics. Clin Physiol 1981;1:285-92.

52. Herve P, Denjean A, Jian R, Simonneau G, Duroux P. Intraesophageal perfusion of acid increases the bronchomotor response to methacholine and isocapnic hyperventilation in asthmatic subjects. Am Rev Respir Dis $1986 ; 134: 986-9$.

53. Andersen LI, Schmidt A, Bundgaard A. Pulmonary function and acid application in the esophagus. Chest 1986;90:358-63.

54. Ducolone A, Vandevenne A, Jouin H, et al. Gastroesophageal reflux in patients with asthma and chronic bronchitis. Am Rev Respir Dis 1987; 135:327-32.

55. Harper PC, Bergner A, Kaye DM. Antireflux treatment for asthma. Improvement with associated gastroesophageal reflux. Arch Intern Med 1987; 147:56-60.

56. Ekstrom T, Tibbling L. Gastro-oesophageal reflux and triggering of bronchial asthma: a negative report. Eur J Respir Dis 1987;71:177-80.

57. Rauscher H, Popp W, Ritschka L. Effect of short esophageal acidification on airway hyperreactivity. Respiration 1989;55:11-5.

58. Tan WC, Martin RJ, Pandey R, Ballard RD. Effects of spontaneous and simulated gastroesophageal reflux on sleeping asthmatics. Am Rev Respir Dis 1990;141:1394-9.

59. Schan CA, Harding SM, Haile JM, Bradley LA, Richter JE. Gastroesophageal reflux-induced bronchoconstriction. An intraesophageal acid infusion study using state-of-the-art technology. Chest 1994;106:731-7.

60. Jakes ME, Agran P, Ong KS. Does gastroesophageal reflux (GER) or low $\mathrm{pH}$ in the lower esophagus (LE) cause bronchoconstriction? Chest 1982;82:246. (Abst)

61. Spaulding HS, Mansfield LE, Stein MR, Sellner JC, Gremillion DE. Further investigation of the association between gastroesophageal reflux and bronchoconstriction. J Allergy Clin Immunol 1982;69:516-21.

62. Perpina M, Pellicer C, Marco V, Maldonado J, Ponce J. The significance of the reflex bronchoconstriction provoked by gastroesophageal reflux in bronchial asthma. Eur J Respir Dis 1985;66:91-7.

63. Field SK. A critical review of the studies of the effects of simulated or real gastroesophageal reflux on pulmonary function in asthmatic adults. Chest 1999;115:848-56. 
64. Wynne JW, Ramphal R, Hood CI. Tracheal mucosal damage after aspiration: ascanning electron microscope study. Am Rev Respir Dis $1981 ; 124: 728-32$.

65. Mendelsohn CL. The aspiration of stomach contents into the lungs during obstetric anaesthesia. Am J Obstet Gynecol 1946;52:191205.

66. Gastal OL, Castell JA, Castell DO. Frequency and site of gastroesophageal reflux in patients with chest symptoms. Studies using proximal and distal pH monitoring. Chest 1994;106:1793-6.

67. Larrain A, Carrasco E, Galleguillos F, Sepulveda R, Pope CE. Medical and surgical treatment of nonallergic asthma associated with gastroesophageal reflux. Chest 1991;99:1330-5.

68. Nagel RA, Brown P, Perks WH, Wilson R, Kerr GD. Ambulatory pH monitoring of gastro-oesophageal reflux in "morning dipper" asthmatics. BMJ 1988;297:1371-3.

69. Gustafsson PM, Kjellman N-I, Tibbling L. A trial of ranitidine in asthmatic children and adolescents with or without pathological gastro-oesophageal reflux. Eur Respir J 1992;5:201-6.

70. Nathan RA, Segall N, Glover GC, Schocket AL. The effects of $\mathrm{H} 1$ and $\mathrm{H} 2$ antihistamines on histamine inhalation challenges in asthmatic patients. Am Rev Respir Dis 1979;120:1251-8.

71. Tashkin DP, Ungerer R, Wolfe R, Mendoza G, Calvarese B. Effect of orally administered cimetidine on histamine- and antigen-induced bronchospasm in subjects with asthma. Am Rev Respir Dis 1982;125:691-5.

72. Schacter EN, Brown S, Lach E, Gerstenhaber B. Histamine blocking agents in healthy and asthmatic subjects. Chest 1982;82:143-7.

73. Bergstrand H, Hegardt B, Lowhagen O, Strannegard O, Svedmyr N. Effects of long-term treatment with low dose cimetidine on allergen-induced airway responses andselected immunological parameters in atopic asthmatics. Allergy 1985;40:187-97.

74. Jackson PJ, Manning PJ, O'Byrne PM. A new role for histamine H2-receptors in asthmatic airways. Am Rev Respir Dis 1988;138:784-8.

75. Hofman J, Rutkowski R, Michalska I. Comparison of the effects of cimetidine and ranitidine in histamine provocation tests in atopic asthma. Agents Actions 1989;27:202-4.

76. Field SK, Sutherland LR. Does medical antireflux therapy improve asthma in asthmatics with gastroesophageal reflux? Chest 1998;114:275-83.

77. Meier JH, McNally PR, Punja M, et al. Does omeprazole (Prilosec) improve respiratory function in asthmatics with gastroesophageal reflux? A double-blind, placebo-controlled crossover study. Dig Dis Sci 1994;39:2127-33.

78. Teichtahl H, Yeomans ND, Kronborg IJ, Robinson P. Adult asthma and gastro-oesophageal reflux: the effects of omeprazole therapy on asthma. Aust NZ J Med 1996;26:671-6.

79. Levin TR, Sperling RM, McQuaid R. Omeprazole improves peak expiratory flow rate and quality of life in asthmatics with gastroesophageal reflux. Am J Gastroenterol 1998;93:1060-3.

80. Boeree MJ, Peters FTM, Postma DS, Kleibeuker JH. No effects of high-dose omeprazole in patients with severe airway hyperresponsiveness and (a)symptomatic gastro-oesophageal reflux. Eur Respir J 1998;11:1070-4.

81. Gencer M, Kyyan E, Erkan F, Demyr K, Cuhadaroglu C, Erelel M. Medical antireflux therapy improves quality of life in adult asthmatics with gastroesophageal reflux. Eur Respir J 1999; 14:106S. (Abst)

82. Field SK, Gelfand GAJ, McFadden SD. The effects of antireflux surgery on asthmatics with gastroesophageal reflux. Chest 1999;116:766-74.

83. Sontag SJ, O'Connell S, Khandelwal S, et al. Antireflux surgery in asthmatics with reflux (GER) improves pulmonary symptoms and function. Gastroenterology1990;98:A128. (Abst)

84. Rothenberg SS, Bratton D, Larsen G, et al. Laparoscopic fundoplication to enhance pulmonary function in children with severe reactive airway disease and gastroesophageal reflux disease. Surg Endosc 1997;11:1088-90.

85. Henderson RD, Woolfe CR. Aspiration and gastroesophageal reflux.Can J Surg 1978;21:352-4.

86. Sontag S, O'Connell S, Greenlee $\mathrm{H}$, et al. Is gastroesophageal reflux a factor in some non-allergenic asthmatics? Am J Gastroenterol 1987;82:119-26.

87. Lomasney TL. Hiatus hernia and the respiratory tract. Ann Thorac Surg 1977;24:448-50.
88. Foglia RP, Fonkalsrud EW, Ament ME, et al. Gastroesophageal fundoplication for the management of chronic pulmonary disease in children. Am J Surg 1980;140:72-7.

89. Berquist WE, Rachelefsky GS, Kadden M, et al. Gastroesophageal reflux-associated recurrent pneumonia and chronic asthma in children. Pediatrics 1981;68:29-35.

90. Johnson DG, Syme WC, Matlak ME, Black RE, Herbst SJ. Gastrooesophageal reflux and respiratory disease: the place of the surgeon. Aust NZ J Surg 1984;54:405-15.

91. Ribet M, Pruvot FR, Mensier E, Ghoch K, Rousseau B. Gastrooesophageal reflux andrespiratory disorders treated by Hill's procedure. Eur J Cardiothorac Surg 1989;3:414-8.

92. Bittner HB, Meyers WC, Brazer SR, Pappas TN. Laparascopic Nissen fundoplication: operative results and short-term follow-up. Am J Surg 1994;167:193-200.

93. Davis MV. Evolving concepts regarding hiatus hernia and gastroesophageal reflux. Ann Thorac Surg 1969;7:120-33.

94. Klotz SD, Moeller RK. Hiatal hernia and intractable bronchial asthma. Ann of Allergy 1971;29:325-8.

95. Iverson LIG, May IA, Samson PC. Pulmonary complications in benign esophageal disease. Am J Surg 1973;126:223-8.

96. Pellegrini CA, DeMeester TR, Johnson LF, Skinner DB. Gastroesophageal reflux and pulmonary aspiration: incidence, functional abnormality and results of surgical therapy. Surgery 1979;86:110-9.

97. Demeester TR, Bonavina L, Iascone C, Courtney JV, Skinner DB. Chronic respiratory symptoms and occult gastroesophageal reflux. Prospective clinical study and results of surgical therapy. Ann Surg 1990;211:337-45.

98. Babb RR, Notarangelo J, Smith VC. Wheezing: a clue to gastroesophageal reflux. Am J Gastroenterol 1970;53:230-3.

99. Christie DL, O'Grady LR, Mack DV. Incompetent lower esophageal sphincter and gastroesophageal reflux in recurrent acute pulmonary disease of infancy and childhood. J Pediatr 1978;93:23-7.

100. Tardif C, Nouvet G, Denis P, Tombelaine R, Pasquis P. Surgical treatment of gastroesophageal reflux in ten patients with severe asthma. Respiration 1989;56:110-5.

101. Buts JP, Barudi C, Moulin D. Prevalence and treatment of silent gastro-oesophageal reflux in children with recurrent respiratory disorders. Eur J Pediatr 1986;145:396-400.

102. Alexander R, Kopita J, Kussin I, Pappas T, Brazer S, Kussin P. Outcome of laparoscopic Nissen fundoplication for asthma associated with refractory gastroesophageal reflux: evidence for clinical benefit at one year follow-up. Am J Respir Crit Care Med 1994;149:A202. (Abst)

103. Hunter JG, Trus TL, Branum GD, Waring JP, Wood WC. A physiologic approach to laparoscopic fundoplication for gastroesophageal reflux disease. Ann Surg 1996;223:673-87.

104. Spivak H, Smith CD, Phichith A, Galloway K, Waring JP, Hunter JG. Asthma and gastroesophageal reflux: fundoplication decreases need for systemic corticosteroids. J Gastrointest Surg 1999;3:477-82.

105. Ruth M, Bake B, Sandberg N, Olbe L, Lundell L. Pulmonary function in gastro-oesophageal reflux disease - effect of reflux control by fundoplication. Dis Esophagus 1994;7:268-75.

106. Irwin RS, Zawacki JK, Curley FJ, French CL, Hoffman PJ. Chronic cough as the sole manifestation of gastroesophageal reflux. Am Rev Respir Dis 1989;140:1294-300.

107. Ing AJ, Ngu MC, Breslin ABX. Chronic persistent cough and gastrooesophageal reflux. Thorax 1991;46:479-83.

108. Fitzgerald JM, Allen CJ, Craven MA, Newhouse MT. Chronic cough and gastroesophageal reflux. CMAJ 1989;140:520-4.

109. Orringer MB. Respiratory symptoms and esophageal reflux. Chest 1979;76:618-9.

110. Pratter MR, Curley FJ, Dubois J, Irwin RS. Cause and evaluation of chronic dyspnea in a pulmonary disease clinic. Arch Intern Med 1989;149:2277-82.

111. DePaso WJ, Winterbauer RH, Lusk JA, Dresi DF, Springmeyer SC. Chronic dyspnea unexplained by history, chest roentgenogram and spirometry. Analysis of a seven year experience. Chest 1991;100:1293-9.

112. Sarton E, Dahan A, Teppema L, et al. Acute pain and central nervous system arousal do not restore impaired hypoxic ventilatory response during sevoflurane sedation. Anesthesiology 1996;85:295-303.

113. Killian KJ, Campbell EJM. Dyspnea. In: Roussos C, ed. The Thorax: 
Lung Biology in Health and Disease, 2nd ed. New York: Marcel Dekker, 1995:1709-41.

114. Field SK, Evans JA, Price LM. The effects of acid perfusion of the esophagus on ventilation and respiratory sensation. Am J Respir Crit Care Med 1998;157:1058-62.

115. Joyce DP, Chapman KR, Kesten S. Prior diagnosis and treatment of patients with normal results of methacholine challenge and unexplained respiratory symptoms. Chest 1996;109:697-701.

116. Ferrari M, Olivieri M, Sembenini C, et al. Tussive effect of capsaicin in patients with gastroesophageal reflux without cough. Am J Respir Crit Care Med 1995;151:557-61.

117. Harding SM, Richter JE, Guzzo M, Schan CA, Alexander RW, Richter
JE. Asthma and gastroesophageal reflux: acid suppressive therapy improves asthma outcome. Am J Med 1996;100:395-405.

118. Juniper EF, Kline PA, Vanzieleghem MA, Ramsdale EH, O’Byrne PM, Hargreave FE. The effect of long-term treatment with an inhaled corticosteroid (budesonide) on airway hyperresponsiveness and clinical asthma in non-steroid dependent asthmatics. Am Rev Respir Dis 1990;142:832-6.

119. Boulet L-P, Becker A, Berube D, Beveridge R, Ernst P. Canadian asthma consensus group. Canadian asthma consensus report. CMAJ 1999;161:S1-62.

120. Global Initiatives for Asthma. [NIH pub no. 95-3659]. Bethesda: National Institutes of Health, 1995. 


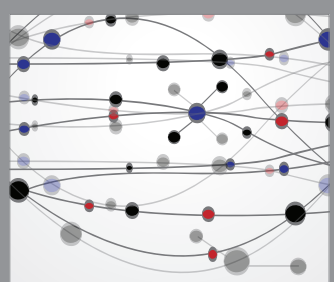

The Scientific World Journal
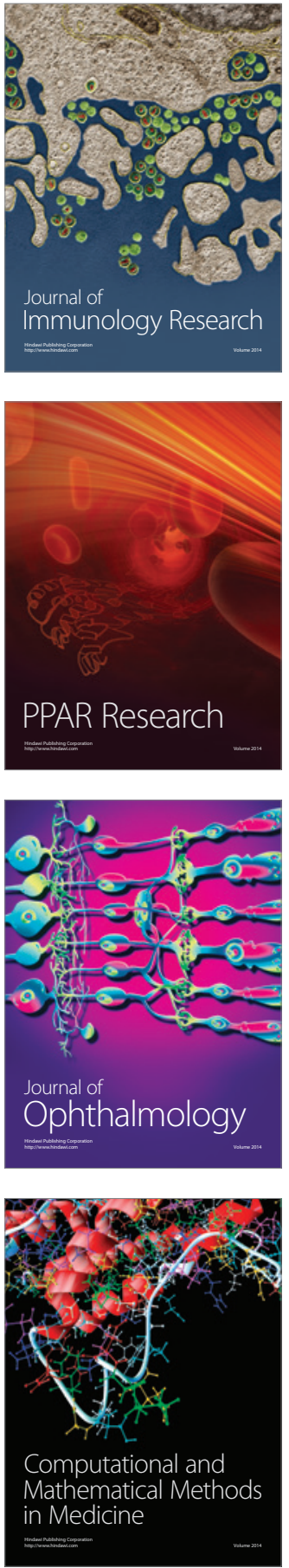

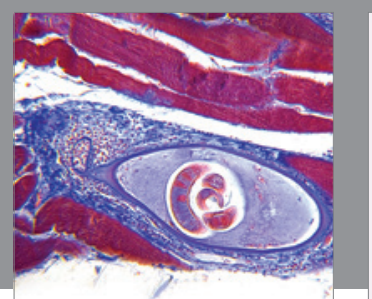

Gastroenterology Research and Practice

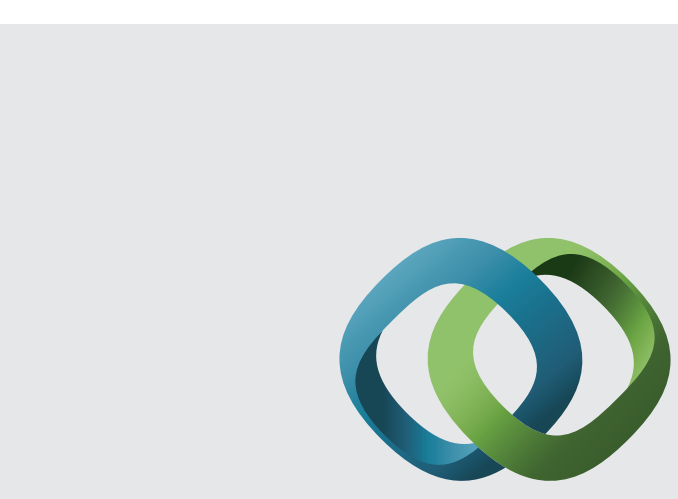

\section{Hindawi}

Submit your manuscripts at

http://www.hindawi.com
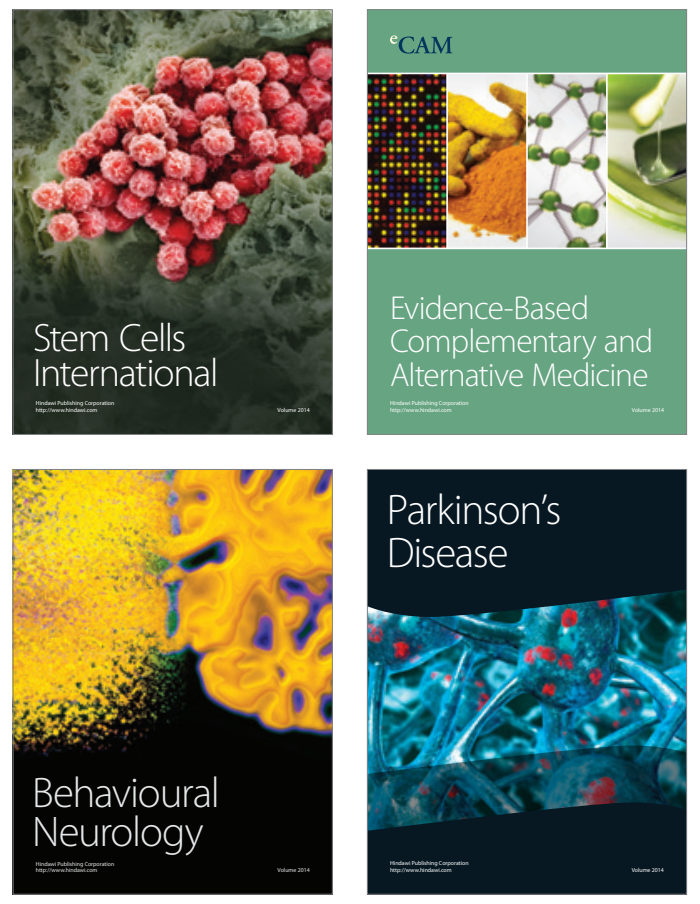
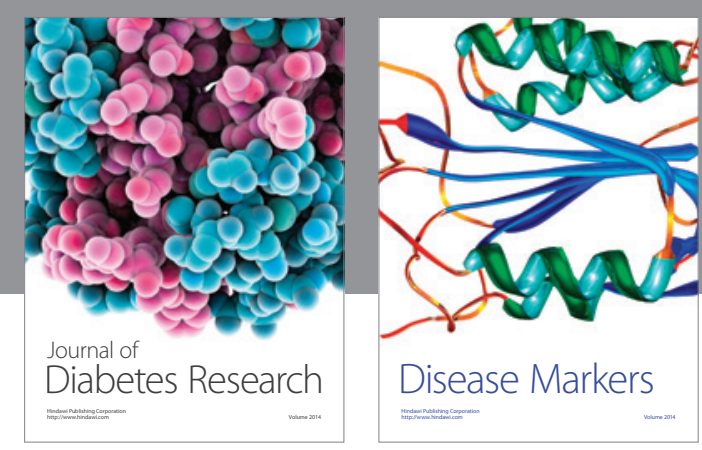

Disease Markers
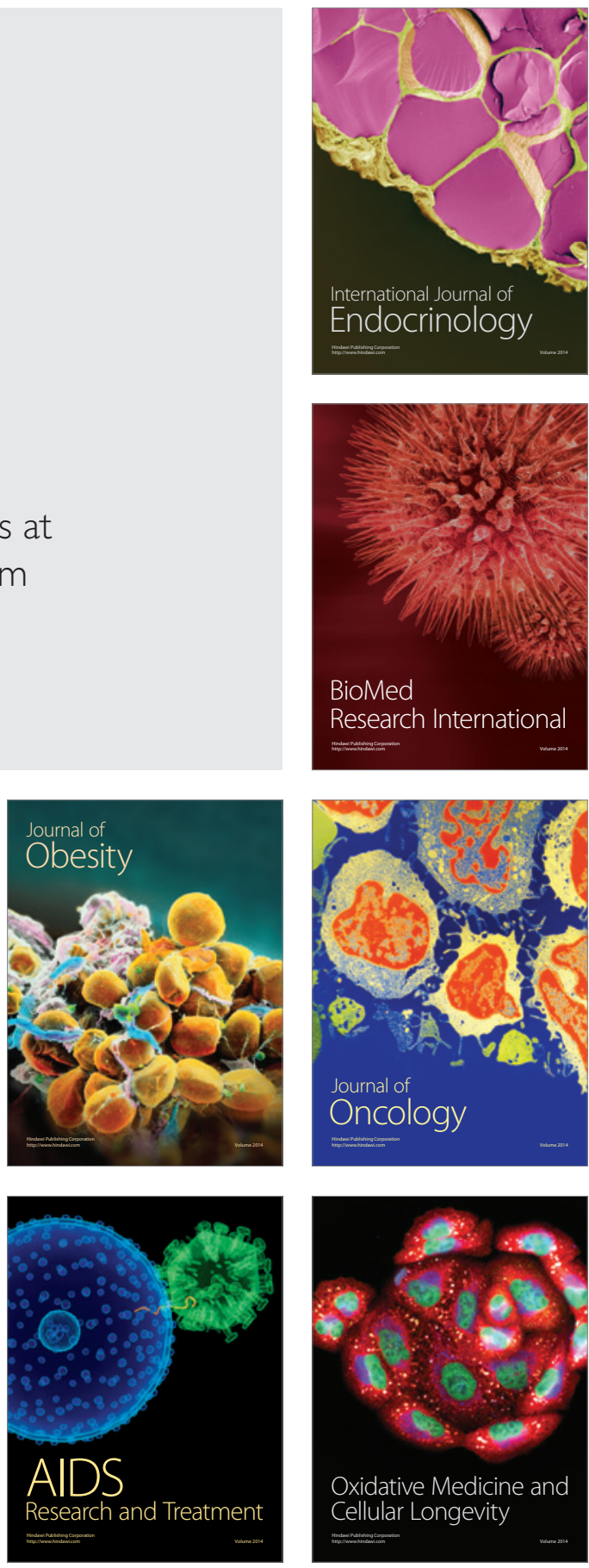